Hal 17-26

\title{
PENTINGNYA TEAM BASED LEARNING (TBL) PADA MAHASISWA KEPERAWATAN UNTUK MENINGKATKAN KERJASAMA TIM: A LITERATURE REVIEW
}

\author{
Wahyu Riyaningrum ${ }^{1}$, Nur Isnaeni ${ }^{2}$ Elsye Maria Rosa ${ }^{3}$ \\ Dosen Fakultas Ilmu Kesehatan Universitas Muhammadiyah Purwokerto ${ }^{1,2}$ \\ Dosen Universitas Muhammadiyah Yogyakarta ${ }^{3}$ \\ Email : wahyuriyaningrum@gmail.com
}

\begin{abstract}
ABSTRAK
Latar Belakang: Metode pembelajaran Team Based Learning (TBL) sebagai salah satu metode pembelajaran yang saat ini banyak digunakan di negara maju. TBL dapat meningkatkan belajar mahasiswa dalam kerjasama kelompok, mahasiswa sangat terlibat aktif dalam proses kegiatan belajar untuk memecahkan masalah sambil mengembangkan kompetensi professional. Faktor internal TBL dipengaruhi oleh motivasi, pengendalian diri dan manajemen diri mahasiswa. Tujuan: Literatur review ini menganalisis tentang metode TBL terhadap kerjasama tim. Metode: Penelitian ini menggunakan pendekatan study literature dengan menggunakan beberapa sumber yang dipilih berdasarkan kriteria inklusi dan ekslusi yang telah ditetapkan peneliti, artikel yang digunakan publish pada tahun 2011-2017. Hasil: Delapan artikel dipakai dalam review, menunjukkan peningkatan yang signifikan dalam skor rata-rata mahasiswa yang dirasakan pada kerja tim. TBL memfasilitasi pembelajaran mahasiswa secara aktif melalui penggunaan kelompok kecil. TBL lebih efektif dari pada pembelajaran konvensional. Kesimpulan: Metode Pembelajaran berbasis tim atau Team Based Learning (TBL) dapat mengembangkan kemampuan bekerjasama dalam tim dengan pendekatan pembelajaran yang mendorong mahasiswa untuk berperan aktif dalam melakukan proses belajarnya.
\end{abstract}

Kata kunci: Team Based Learning (TBL), mahasiswa keperawatan, kerjasama tim.

\begin{abstract}
Background: Team Based Learning (TBL) learning method as a learning method that is currently widely used in developed countries. TBL can improve student learning in group collaboration, students are very actively involved in the process of learning activities to solve problems while developing professional competencies. TBL internal factors are influenced by student motivation, selfcontrol and self-management. Objective: This literature review analyzes the TBL method of teamwork. Method: This study uses a literature study approach used several sources selected based on criteria established by researchers, the articles used were published in 2011-2017. Results: Eight articles were used in the review, shows a significant increase in the student's perceived mean score on teamwork. TBL facilitates active student learning through the use of small groups. TBL is more effective than conventional learning. Conclusion: Team Based Learning (TBL) can develop the ability to work in teams with a learning approach that encourages students to take an active role in carrying out the learning process.
\end{abstract}

Keywords: Team Based Learning (TBL), nursing students, teamwork 


\section{Latar Belakang}

Pembelajaran modern dalam kegiatan belajar saat ini semakin sedikit menggunakan pendekatan terstuktur tetapi lebih banyak tugas belajar mandiri dipandu melalui konsultasi dengan akademisi (Stewart, 2007). Mahasiswa diharapkan memiliki kemampuan mengembangkan keterampilan pemikiran analitis dan kritis untuk menanggapi masalah dan mengembangkan kemampuan interaksi serta kerjasama lebih baik, metode pembelajaran yang digunakan untuk memperbaiki metode pembelajaran satu arah yang telah ada saat ini salah satunya yaitu pembelajaran Team Based Learning (TBL) (Tyas, 2017).

Metode pembelajaran yang saat ini banyak digunakan pada berbagai perguruan tinggi di negara-negara maju, termasuk di Indonesia salah satu nya yaitu metode pembelajaran TBL. Peraturan Menteri Pendidikan Nasional SK No. 045/U/202 tentang Kurikulum Pendidikan Tinggi yang berbasis Kompetensi menyebabkan sistem pendidikan perguruan tinggi di Indonesia mengalami perubahan paradigma pendidikan. Pendidikan di bidang ilmu kesehatan mengalami perubahan pada pola dan cara belajar mahasiswa. Keperawatan merupakan salah satu pendidikan ilmu kesehatan yang memerlukan perhatian dengan perubahan paradigma tersebut (DIKTI, 2014).

Metode pembelajaran TBL dapat meningkatkan belajar mahasiswa dalam kerjasama kelompok, mahasiswa sangat terlibat dalam proses kegiatan belajar, hasilnya sangat signifikan bagi mahasiswa dengan menggunakan metode pembelajaran TBL dari pada menggunakan metode pembelajaran konvensional/ Teacher Center Learning (TCL) (Jafari, 2018). TBL lebih efektif dari pada pembelajaran konvensional, mahasiswa akan lebih terlibat dalam mempersiapkan diri dalam kelas serta hasil belajar dapat meningkat (Allen et al., 2013).

TBL memfasilitasi pembelajaran aktif melalui penggunaan kelompok kecil pada kegiatan kelas, mahasiswa menggunakan waktu di kelas untuk memecahkan masalah sambil mengembangkan kompetensi profesional yang penting, aktivitas yang berpusat pada mahasiswa namun mengharuskan mahasiswa untuk bekerja dalam tim untuk menerapkan konten yang dipelajari dalam memecahkan masalah serta bertujuan untuk meningkatkan pembelajaran serta pengembangan kepercayaan pada nilai bekerja dalam tim. Keterampilan pengambilan keputusan klinis yang cerdas dan kompetensi professional yang disempurnakan seperti keterampilan interpersonal dan kerja tim sangat penting untuk perawat dan prasyarat untuk melakukan asuhan keperawatan kepada pasien yang berkualitas (Ratta, 2015). Berdasarkan permasalahan tersebut, literatur review ini menganalisis tentang pentingnya TBL pada mahasiswa keperawatan terhadap peningkatan kerjasama tim. 


\section{Metode}

Studi ini dilakukan melalui tiga tahap: 1) Memanfaatkan database akademik, penyusun mencari dan mengambil artikel dan sumber daya yang relevan dengan topik yang dikaji. 2) Penyusun memilih artikel dan sumber yang diambil untuk mengidentifikasi jurnal yang paling mungkin menawarkan data pendukung. 3) Penyusun mengumpulkan informasi, dan tabel data, dengan harapan mengidentifikasi dan memprioritaskan intervensi. Database digunakan dalam proses pencarian penyusun, termasuk Sumber Pubmed, Proquest, Google Scholar dan JPKI. Kata kunci dan istilah pencarian yang digunakan: Team Based Learning (TBL), mahasiswa keperawatan,

\section{Hasil}

Hasil kajian literatur ini mengidentifikasikan delapan artikel yang memenuhi kriteria inklusi. Sebagian besar makalah membahas tentang metode pembelajaran TBL pada mahasiswa keperawatan. Artikel yang ditulis dalam Bahasa Indonesia 3 artikel, sedangkan 5 artikel lainnya ditulis dalam bahasa Inggris. Jenis penelitian yang digunakan adalah penelitian kuantitative untuk mengetahui keefektifitasan metode pembelajaran TBL dan penelitian kualitatif disini untuk mengetahui faktor-faktor yang berperan besar dalam memahami pembelajaran mahasiswa melalui kerja kelompok kecil dari perspektif mahasiswa dan pendidik. Hasil literature review dapat dilihat pada tabel 1.

kerjasama tim.

\begin{tabular}{|c|c|c|c|c|c|c|}
\hline No & $\begin{array}{c}\text { Author } \\
\text { (year) }\end{array}$ & Tittle & $\begin{array}{c}\text { Design and } \\
\text { data collection } \\
\text { methods }\end{array}$ & Aim & Findings & Component \\
\hline 1. & $\begin{array}{l}\text { (Park et } \\
\text { al., 2015) }\end{array}$ & $\begin{array}{l}\text { Effects of TBL on perceived } \\
\text { team work and academic } \\
\text { performance in a health } \\
\text { assessment subject }\end{array}$ & $\begin{array}{l}\text { Quantitative } \\
\text { A prospective } \\
\text { one-group, pre- } \\
\text { and post-test }\end{array}$ & 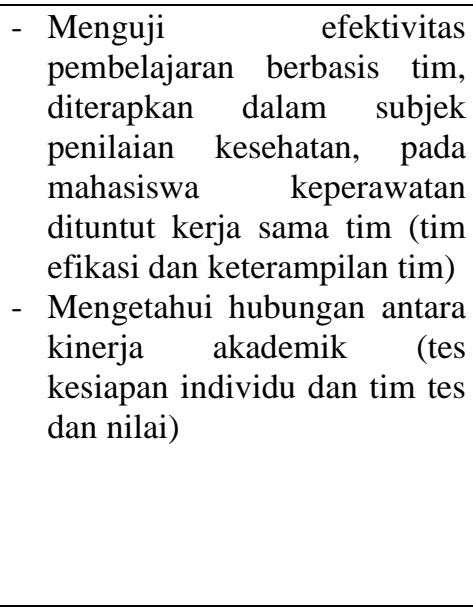 & 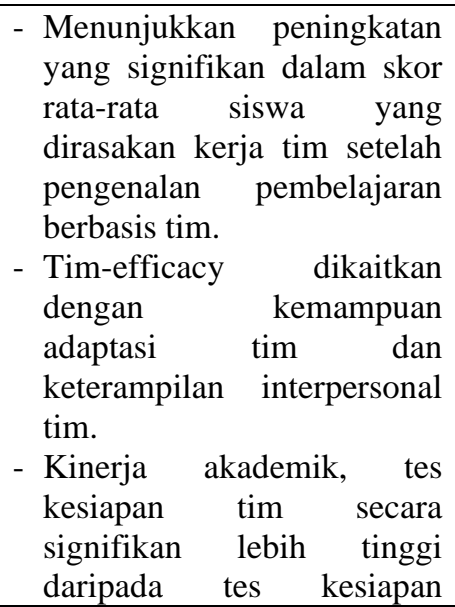 & $\begin{array}{l}\text { - } \text { TBL } \\
\text { - } \text { Tim efficacy } \\
\text { - Kesiapan } \\
\text { individu }\end{array}$ \\
\hline
\end{tabular}




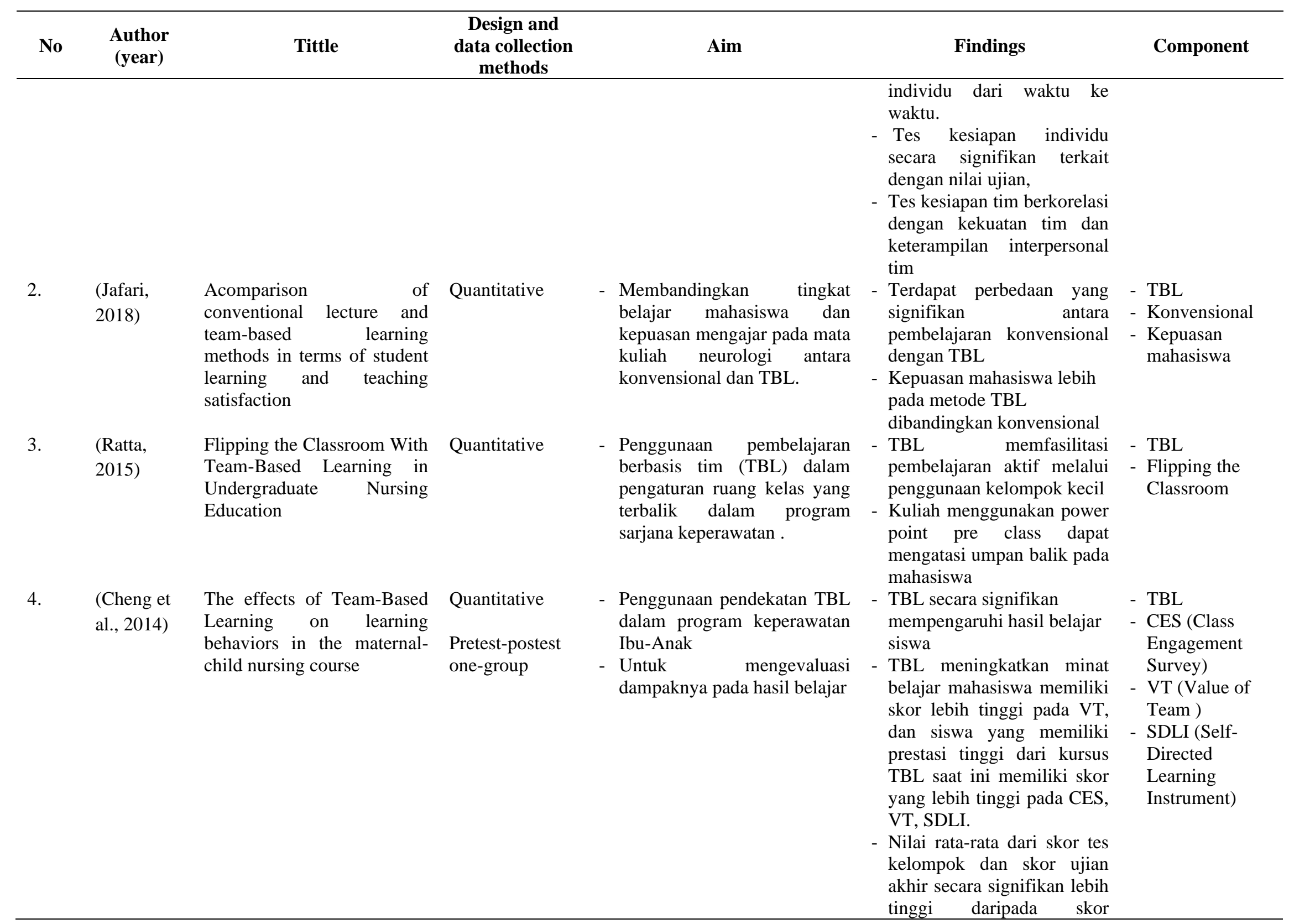




\begin{tabular}{|c|c|c|c|c|c|c|}
\hline No & $\begin{array}{c}\text { Author } \\
\text { (year) }\end{array}$ & Tittle & $\begin{array}{c}\text { Design and } \\
\text { data collection } \\
\text { methods }\end{array}$ & Aim & Findings & Component \\
\hline 5. & $\begin{array}{l}\text { (Tyas., } \\
\text { 2017) }\end{array}$ & $\begin{array}{l}\text { Perbedaan Metode Team } \\
\text { Based Learning Dengan } \\
\text { Metode Ceramah Terhadap } \\
\text { Peningkatan Kemampuan } \\
\text { Berpikir Kritis Mahasiswa } \\
\text { Keperawatan }\end{array}$ & $\begin{array}{l}\text { Quantitative } \\
\text { Komparatif } \\
\text { Kohort }\end{array}$ & 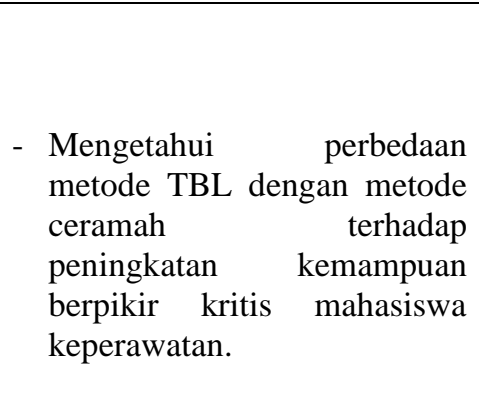 & $\begin{array}{l}\text { individu dari tes di kelas di } \\
\text { kedua 2011, 2012 dan } \\
\text { kombinasi } 2011 \text { dan } 2012 \\
\text { - Ada pengaruh perbedaan } \\
\text { peningkatan kemampuan } \\
\text { berpikir kritis bagi } \\
\text { mahasiswa keperawatan } \\
\text { setelah penerapan metode } \\
\text { TBL dan metode ceramah } \\
\text { ketiga, kelima dan ketujuh. }\end{array}$ & $\begin{array}{l}\text { - } \text { TBL } \\
\text { - } \text { Metode } \\
\text { ceramah } \\
\text { - Kemampuan } \\
\text { berpikir kritis } \\
\text { mahasiswa }\end{array}$ \\
\hline 6. & $\begin{array}{l}\text { (Yunitasari } \\
\text {, 2017) }\end{array}$ & $\begin{array}{l}\text { Pengaruh pembentukan } \\
\text { kelompok belajar dalam } \\
\text { TBL terhadap motivasi } \\
\text { belajar }\end{array}$ & $\begin{array}{l}\text { Quantitative } \\
\text { Quasi } \\
\text { Eksperimen pre- } \\
\text { test-post-test } \\
\text { with control } \\
\text { group }\end{array}$ & 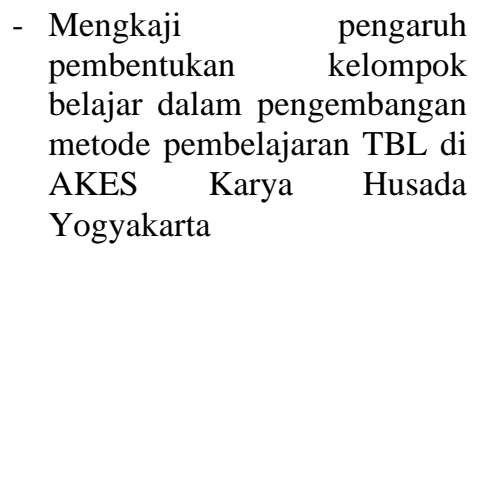 & $\begin{array}{l}\text { - Sebelum perlakuan, baik } \\
\text { kelompok intervensi } \\
\text { maupun kelompok kontrol } \\
\text { mempunyai motivasi yang } \\
\text { relative sama dan tergolong } \\
\text { rendah. } \\
\text { - Setelah intervensi terdapat } \\
\text { peningkatan motivasi } \\
\text { belajar pada kelompok TBL } \\
\text { lebih tinggi dibandingkan } \\
\text { mahasiswa kelompok } \\
\text { ceramah. }\end{array}$ & $\begin{array}{l}\text { - } \text { TBL } \\
\text { - } \text { Metode } \\
\text { ceramah } \\
\text { - Pembentukan } \\
\text { kelompok } \\
\text { belajar } \\
\text { - } \text { Motivasi belajar }\end{array}$ \\
\hline 7. & $\begin{array}{l}\text { (Yunitasari } \\
\text { and } \\
\text { Iswantinin } \\
\text { gsih., } \\
\text { 2017) }\end{array}$ & \begin{tabular}{lrr} 
Penerapan & Metode \\
Pembelajaran & Team Based \\
Learning & \multicolumn{2}{r}{ Terhadap } \\
Pengetahuan, & Sikap Dan Dan \\
Tingkat & Partisipasi \\
Mahasiswa & Prodi & D3 \\
Keperawatan & Akes & Karya \\
Husada Yogyakarta
\end{tabular} & $\begin{array}{l}\text { Quantitative } \\
\text { Cross-sectional }\end{array}$ & $\begin{array}{l}\text { - Melihat pengetahuan dan } \\
\text { sikap mahasiswa terhadap } \\
\text { metode pembelajaran TBL } \\
\text { - Mengetahui tingkat } \\
\text { partisipasi mahasiswa dalam } \\
\text { proses pembelajaran TBL. }\end{array}$ & $\begin{array}{l}\text { - } \begin{array}{l}\text { Tingkat } \\
\text { mahasiswa }\end{array} \text { partisipasi } \\
\text { pembelajaran } \\
\text { kBL dalam } \\
\text { kategori bagus } \\
\text { - Pengetahuan dan sikap } \\
\text { mahasiswa berpengaruh } \\
\text { terhadap tingkat partisipasi } \\
\text { mahasiswa. }\end{array}$ & $\begin{array}{l}\text { - TBL } \\
\text { - Pengetahuan } \\
\text { - Sikap } \\
\text { - Tingkat } \\
\text { partisipasi } \\
\text { mahasiswa }\end{array}$ \\
\hline 8. & $\begin{array}{l}\text { (Wong, } \\
\text { 2018) }\end{array}$ & $\begin{array}{l}\text { A phenomenological } \\
\text { research study: Perspectives } \\
\text { of student learning through } \\
\text { small group work between } \\
\text { undergraduate nursing } \\
\text { students and educators }\end{array}$ & A qualitative & $\begin{array}{ll}\text { - Untuk } & \text { memahami } \\
\text { pembelajaran mahasiswa } & \text { melalui kerja kelompok kecil } \\
\text { dari perspektif mahasiswa } \\
\text { dan pendidik. }\end{array}$ & $\begin{array}{l}\text { Empat tema utama: } \\
\text { 1. Pembelajaran inisiatif } \\
\text { 2. Pemberdayaan dinamika } \\
\text { kelompok Interaktif } \\
\text { 3. Faktor-faktor untuk } \\
\text { menciptakan lingkungan } \\
\text { belajar yang efektif } \\
\text { 4. Hambatan memengaruhi }\end{array}$ & $\begin{array}{l}\text { - Hasil belajar } \\
\text { kelompok kecil } \\
\text { diakui sebagai } \\
\text { metode } \\
\text { pengajaran } \\
\text { yang efektif } \\
\text { untuk } \\
\text { peningkatan }\end{array}$ \\
\hline
\end{tabular}




\begin{tabular}{|c|c|c|c|c|c|c|}
\hline No & $\begin{array}{c}\text { Author } \\
\text { (year) }\end{array}$ & Tittle & $\begin{array}{c}\text { Design and } \\
\text { data collection } \\
\text { methods }\end{array}$ & Aim & Findings & Component \\
\hline & & & & & $\begin{array}{l}\text { belajar mahasiswa } \\
\text { diturunkan mengenai } \\
\text { pembelajaran mahasiswa } \\
\text { dalam kerja kelompok } \\
\text { kecil berdasarkan } \\
\text { perspektif peserta }\end{array}$ & $\begin{array}{l}\text { pengetahuan } \\
\text { dan } \\
\text { pengembangan } \\
\text { keterampilan } \\
\text { dalam } \\
\text { pendidikan } \\
\text { keperawatan. }\end{array}$ \\
\hline
\end{tabular}

\section{Metode Pembelajaran TBL (Team Based Learning)}

Team Based Learning (TBL) atau pembelajaran berbasis tim adalah strategi pembelajaran dan pengajaran berbasis kelompok dan berpusat pada mahasiswa yang menggunakan format terstruktur dari persiapan pre-class, tes kesiapan individu dan kelompok, dan latihan aplikasi (Park et al., 2015). Metode TBL merupakan salah satu dari metode pembelajaran Student Center Learning (SCL), yang meliputi: Small Group Discussion (SGD), Role Play and Simulation, Discovery Learning, Cooperative Learning, Contextual Learning, Problem Based Learning dan Project Based Learning. TBL ini termasuk dalam SGD dimana pembelajarannya berfokus pada kemampuan mahasiswa untuk bekerjasama dalam kelompok kecil-kecil (Yunitasari, 2017). Metode TBL sangat menarik minat mahasiswa, karena pada metode ini mahasiswa dapat lebih efektif dalam belajar dan bekerjasama dalam tim dengan baik menurut Gaspersz (2003) dalam (Yunitasari, 2017).

\section{Faktor-Faktor yang mempengaruhi TBL}

Pembelajaran TBL dapat meningkatkan semangat belajar mahasiswa secara sosial dan akademik, hal ini sebanding dengan pengertian belajar yaitu suatu proses perubahan tingkah laku individu melalui interaksi dengan lingkungan. Sedangkan keberhasilan dari sebuah proses pembelajaran dipengaruhi oleh faktor internal dan ekternal. Faktor dari luar individu (eksternal) yang sering berpengaruh pada kebiasaan belajar adalah sebagai berikut: sikap guru, keadaan ekonomi keluarga, kasih sayang dan perhatian orangtua, sedangkan faktor dari diri individu (internal): motivasi, pengendalian diri dan emosi, kelemahan fisik, dan kelemahan mental (Samad, 2014).

Dua Belas Tips Pembelajaran TBL Gullo et al., (2015)

1. Menggunakan $4 \mathrm{~S}$ untuk menyusun pertanyaan yang menarik: a. Masalah signifikan (Significant problem). 
b. Pilihan khusus (Specific choice).
c. Laporan simultan (Simultaneous report).

2. Memperhatikan waktunya.

3. Membuat strategi proses fasilitasi.

4. Mengingat fasilitasi yang tidak mengirimkan konten

5. Menghindari pemberian jawaban selama fase fasilitasi

6. Memberikan waktu untuk penutupan Serta melibatkan pelajar yang pasiv:

7. Menunggu mahasiswa untuk menjawab pertanyaan

8. Meminta pertanyaan yang netral dan terbuka

9. Meringkas atau mengulangi untuk kejelasan

10. Menemukan "student expert" di kelas

11. Memastikan setiap ketidakpastian atau ketidaksetujuan

12. Mempertahankan tanggung jawab masingmasing mahasiswa.

\section{Langkah-langkah Penerapan Team Based Learning (TBL)}

Terdiri dari tiga fase: Michaelsen et al., (2012) dalam (Huriah, 2018)

1) Tahap Persiapan: Persiapan dari mahasiswa diberi materi untuk belajar sebelum mereka datang ke kelas berupa modul. Persiapan dari dosen yaitu mengidentifikasi tujuan instruksional pembelajaran dan merancang sebuah sistem penilaian.
2) Pertemuan Pertama Kelas: Mengenalkan mahasiswa pada metode TBL, pembentukan kelompok, mengurangi kekhawatiran mahasiswa tentang penilaian, memastikan kemampuan mahasiswa untuk menjamin proses TBL meliputi: Readiness Assurance Test (RAT), di mana mahasiswa mengambil tes individu (IRAT) dan tim (TRAT) untuk menilai pemahaman mereka tentang materi pra-kelas, Appeals dimana mahasiswa diberikan kesempatan untuk menentukan bahan bacaan persiapan materi dan Feedback dari instruktur.

3) Tahap Aplikasi: Mahasiswa melakukan penerapan pembelajaran dengan mengerjakan tugas untuk memecahkan masalah secara bersama-sama dari skenerio dengan akuntabilitas yang baik. Pada tahap ini merupakan tahap yang paling menantang pada pelaksanaan TBL.

\section{Faktor-faktor Kerjasama Tim}

Kerjasama tim merupakan kekuatan dari beberapa orang dalam mencapai tujuan yang sama. Kerjasama dapat menyatukan kekuatan dari ide-ide menuju pada kesuksesan (Cheng et al., 2014). Faktor-faktor kerjasama tim meliputi: kerjasama, kepercayaan dan kekompakan. Faktor-faktor untuk menciptakan lingkungan belajar yang efektif, termasuk preferensi untuk membentuk kelompok, ukuran kelompok yang efektif, dan kecukupan diskusi, memfasilitasi pembelajaran mahasiswa dengan peningkatan keterlibatan pembelajaran dalam kerja kelompok kecil (Wong, 2018). 


\section{Pembahasan}

Tinjauan literatur ini telah menggarisbawahi tentang metode pembelajaran berbasis tim, artikel-artikel yang sudah dilaporkan ternyata menyebutkan mahasiswa dilakukan perlakuan pembelajaran tim dimana mahasiswa dituntut untuk dapat mengikuti proses pembelajaran dan menghadapi permasalahan yang muncul serta menyelesaikannya dalam proses pembelajaran tersebut.

Pada TBL mahasiswa diharapkan memiliki kemampuan berfikir pada saat menghadapi permasalahan dan mengembangkan kemampuan berinteraksi dan bekerjasama yang lebih baik (Tyas, 2017). Kerjasama dalam tim dibangun oleh kepercayaan, semakin tinggi rasa percaya antar anggota tim maka akan semakin baik pula kerjasama tim, sehingga akan memberikan pengaruh terhadap kinerja anggota tim (Lawasi \& Triatmanto, 2017). Kerjasama dapat menyatukan kekuatan dari ide-ide menuju pada kesuksesan dan mencapai tujuan yang sama (Cheng et al., 2014).

\section{Yunitasari, (2017) pembentukan} kelompok pada mahasiswa D3 keperawatan dimana kerjasama secara berkelompok mengarah pada efisien dan efektivitas yang lebih baik, sehingga dapat merangsang seseorang untuk dapat berkontribusi dalam kelompoknya. Pembentukan kelompok berasal dari komposisi tim yang seimbang dimana tim terdiri dari peran dan perilaku yang berbedabeda akan dapat melengkapi satu sama lain
(Belbin, 2015). Kerjasama tim melatih seseorang untuk lebih aktif dalam suatu kelompok dan TBL melatih mahasiswa akan menemukan solusi dari permasalahan yang dihadapi serta banyak mendapatkan wacana atau pengetahuan baru dibandingkan saat seseorang berpikir sendiri.

Jafari, (2018) tentang metode pembelajaran TBL yang menggunakan Student Center Learning (SCL) dapat meningkatkan belajar mahasiswa dalam kerjasama kelompok dimana mahasiswa sangat terlibat dalam proses kegiatan belajar dibandingkan dengan pembelajaran konvensional/ Teacher Center Learning (TCL). TBL dapat memfasilitasi pembelajaran aktif melalui kelompok kecil yang berjumlah 5-7 mahasiswa di dalam kelas. Mahasiswa mampu menggunakan waktu untuk memecahkan masalah sambil mengembangkan kompetensi profesional yang penting. TBL kegiatan berpusat pada mahasiswa namun hal ini mengharuskan mahasiswa untuk bekerjasama dalam tim dan mengembangkan kepercayaan pada nilai bekerja secara bersamasama (Ratta, 2015).

Pada TBL adapun tantangannya terdapat pada saat tugas aplikasi dimana mahasiswa harus memiliki akuntabilitas yang baik dan memastikan diskusi antar anggota kelompok dilanjutkan dengan diskusi antar kelompok pada tahap inilah yang menantang pada pelaksanaan TBL serta konsep pada TBL membutuhkan waktu yang cukup lama (Huriah, 2018). Faktor yang berperan dalam kesiapan penerapan SDL pada mahasiswa meliputi 
karakteristik mahasiswa, proses pembelajaran dan peran tutor/ perseptor serta sarana dan prasarana (Gunanegara et al., 2017). Pembelajaran TBL dapat diterapkan pada kelas besar, sehingga tidak memerlukan banyak kelas seperti halnya pada pelaksanaan pembelajaran tutorial yang memerlukan ruangan banyak serta fasilitator pada tiap ruangan. Metode TBL ini sangat sesuai pada perguruan tinggi yang masih memiliki kekurangan sarana dan prasarana serta SDM yang memadai sesuai dengan rasio mahasiswa untuk dapat mewujudkan proses pembelajaran Student Center Learning (SCL) (Huriah, 2018).

Wong et al., (2017) kerjasama tim dipengaruhi oleh tiga faktor: kerjasama, kepercayaan dan kekompakan masih perlu ditingkatkan kembali untuk pencapaian proses pembelajaran TBL yang fokus utamanya adalah pembelajaran dengan berbasis tim. Wong, (2018) Hasil belajar kelompok kecil diakui sebagai metode pengajaran yang efektif untuk peningkatan pengetahuan dan pengembangan keterampilan dalam pendidikan keperawatan. Dengan kerjasama yang baik dapat merangsang seseorang untuk dapat berkontribusi dalam kelompoknya.

\section{Kesimpulan}

Metode Pembelajaran berbasis tim atau Team Based Learning (TBL) dapat mengembangkan kemampuan bekerjasama dalam tim dengan pendekatan pembelajaran yang mendorong mahasiswa untuk berperan aktif dalam melakukan proses belajar.

\section{Ucapan Terimakasih}

Penulis mengucapkan terima kasih kepada Direktur Universitas Muhammadiyah Purwokerto dan Ketua Lembaga Penelitian dan Pengabdian Masyarakat yang telah memberikan dukungan dalam penyelesaian publikasi ini.

\section{Daftar Pustaka}

Allen, R.E., Copeland, J., Franks, A.S., Karimi, R., McCollum, M., Riese, D.J., Lin, A.Y., 2013. Team-based learning in US colleges and schools of pharmacy. Am. J. Pharm. Educ. 77, 115.

Belbin., 2015. The Way Forward For Innovation Team. Journal of creativity and business innovation vol.1.

Cheng, C.-Y., Liou, S.-R., Tsai, H.-M., Chang, C.-H., 2014. The effects of Team-Based Learning on learning behaviors in the maternal-child nursing course. Nurse Educ. Today 34, 25-30. https://doi.org/10.1016/j.nedt.2013.03.0 13

Gullo, C., Ha, T.C., Cook, S., 2015. Twelve tips for facilitating team-based learning. Med. Teach. 37, 819-824. https://doi.org/10.3109/0142159X.2014. 1001729

Gunanegara, R.F., Wahid, M.H., Widyahening, I.S., 2017. Comparison of Students' Characteristics, Self-Motivation, and Readiness of Self-Directed Learning Implementation among Medical Students at Maranatha Christian University. J. Med. Health 1.

Huriah, T., 2018. Metode Student Center Learning Aplikasi pada Pendidikan Keperawatan. Jakarta: Prenadamedia Group. 
Jafari, Z., 2018. A Comparison Of Conventional Lecture And Team-Based Learning Methods In Terms Of Student Learning And Teaching Satisfaction 28, 8.

Lawasi, E.S., Triatmanto, B., 2017. Pengaruh Komunikasi, Motivasi, dan Kerjasama tim terhadap Peningkatan Kinerja Karyawan. J. Manaj. Dan kewirausahaan 5. https://doi.org/10.26905/jmdk.v5i1.131 3

Park, H.-R., Kim, C.-J., Park, J.-W., Park, E., 2015. Effects of team-based learning on perceived teamwork and academic performance in a health assessment subject. Collegian 22, 299-305.

https://doi.org/10.1016/j.colegn.2014.05 .001

Pedoman Kurikulum., 2014. Asosiasi Institusi Pendidikan Ners. Indonesia

Ratta, C.B.D., 2015. Flipping the Classroom With Team-Based Learning in Undergraduate Nursing Education: Nurse Educ. 40, 71-74. https://doi.org/10.1097/NNE.00000000 00000112

Samad, A.A., 2014. Investigating The Implementation Of Team-Based Learning In A University Level Teacher Education Course. Int. J. Asian Soc. Sci. 9.

Stewart, R., 2007. Investigating the link between self-directed learning readiness and project-based learning outcomes. European Journal of Engineering education 32 (4) , 453-465

Tyas, L.W., 2017. Perbedaan Metode Team Based Learning Dengan Metode Ceramah Terhadap Peningkatan Kemampuan Berpikir Kritis Mahasiswa Keperawatan 6, 7.

Wong, A.K.C., Wong, F.K.Y., Chan, L.K., Chan, N., Ganotice, F.A., Ho, J., 2017.
The Effect Of Interprofessional TeamBased Learning Among Nursing Students: A Quasi-Experimental Study. Nurse Educ. Today 53, 13-18. https://doi.org/10.1016/j.nedt.2017.03.0 04

Wong, F.M.F., 2018. A Phenomenological Research Study: Perspectives Of Student Learning Through Small Group Work Between Undergraduate Nursing Students And Educators. Nurse Educ. Today 68, 153-158. https://doi.org/10.1016/j.nedt.2018.06.0 13

Yunitasari, P., 2017. Pengaruh Pembentukan Kelompok Belajar Dalam Team Based Learning Terhadap Motivasi Belajar Mahasiswa Prodi DIII Keperawatan Akademi Kesehatan Karya Husada Yogyakarta 12, 6.

Yunitasari, P., Iswantiningsih, E.E., 2017. Penerapan Metode Pembelajaran Team Based Learning Terhadap Pengetahuan, Sikap Dan Tingkat Partisipasi Mahasiswa Prodi DIII Keperawatan Akes Karya Husada Yogyakarta 8. 